\title{
Characterization and Mapping Land Degradation Hotspots in the Terrestrial Ecosystem of Kuwait
}

\author{
Abeer H Al Saleh*, Raafat F Misak, Salman A Al Tamimi, Haya Al Baker and Mariam J Malek \\ Kuwait Institute for Scientific Research Kuwait \\ *Corresponding author: Abeer H Al Saleh, Kuwait Institute for Scientific Research Kuwait
}

\begin{abstract}
ARTICLE INFO
Received: 蔧 January 22, 2019

Published: 慧 February 05, 2019

Citation: Abeer H Al Saleh, Raafat F Misak, Salman A Al Tamimi, Haya Al Baker, Mariam J Malek. Characterization and Mapping Land Degradation Hotspots in the Terrestrial Ecosystem of Kuwait. Biomed J Sci \& Tech Res 14(1)-2019. BJSTR. MS.ID.002487.
\end{abstract}

Keywords: Desert Areas; Ground Truth; Land Degradation Indicators; Land Use; Vegetation Cover

Abbreviations: LDH: Land Degradation Hotspots; GIS: Geographic Information System; GPS: global positioning system; LDN: Land Degradation Neutrality

\begin{abstract}
Land degradation processes prevail in about $50.6 \%$ of the terrestrial ecosystem of Kuwait. This ecosystem which covers about 15,000 $\mathrm{km}^{2}$ (about $85 \%$ of Kuwait) is dotted by a high number of land degradation hotspots (LDH). A hot spot is a severely degraded area, where land degradation indicators are observable. The main objectives of this study are to detect land degradation hotspots and to quantify the impact of land uses on the natural vegetation and soil types. Detection of land degradation hot spots is a significant prerequisite for Land degradation control. The land degradation hotspots were delineated and characterized using Geographic Information System (ArcGIS S/W 10.5) and satellite image (Landsat 8 of September 2017). A ground truth activity followed the Landsat analyses. The approach of detection and mapping land degradation hotspots is simple and applicable in Kuwait and the surrounding countries. The results of the study showed 58 hotspots with a total area of about $7590.3 \mathrm{Km}^{2}$ (50.6 \% of the terrestrial environment). The study reveals a significant variation in the areas, land use and indicators of land degradation of the hotspots. The areas range from about $2000 \mathrm{~km} 2$ to $1.2 \mathrm{~km}^{2}$. In all of the hot spots, the soils, vegetation cover and micro land features are highly degraded due to destructive land use types including overgrazing, offroad vehicles, camping and recreation, and soil mining. The total length of off-road vehicles is around 14,774.67 Km ( $0.98 \mathrm{Km} /$ $\mathrm{Km}^{2}$ ) and the percentage of degraded vegetation and disturbed soil was $48.7 \%$ and $47 \%$ respectively.
\end{abstract}

\section{Introduction}

In Kuwait, the lack of quantitative information and georeferenced data on the extent of degraded lands represents one of the significant challenges facing the development of an action plan for land degradation control. Application of remote sensing and GIS, besides ground truth and intensive field surveys, is a practical and cost-effective tool for mapping and characterization of land degradation. In the present study, the term land degradation hotspots (LDH) is used to characterize areas of different sizes, where the vegetation cover and the soil types are severely degraded. Degradation was caused by excessive human pressure under drought conditions. The past land uses for the majority of the hotspots were rangeland grazing and seasonal recreation activities. The vegetation map [1] indicates that the lands of the hot spots were covered with perennial vegetation. The present study indicates that this perennial vegetation is totally disappeared, and the soils are highly degraded due to destructive land use types.
The most common soil degradation processes are soil losses (by both wind and water), soil compaction and sealing and soil mining. Currently, the majority of the hotspots act as anthropogenic sources for sands and dust (through offroad vehicles). Figure 1 Shows the interaction between land use types and the status of vegetation.

Kuwait covers $17,800 \mathrm{~km}^{2}$. It consists of two main ecosystems. These are the terrestrial (about 85\%) and the coastal and marine (15\%). The harsh environmental conditions of Kuwait (including prolonged drought such as that of 2007 to 2017 besides land misuse and over-exploitation of soils and vegetation are the main driving forces for land degradation. Some $75.1 \%$ of the lands of Kuwait is used for grazing activities and desert recreation [2]. During the last three decades, the terrestrial environment in Kuwait was subjected to different mechanisms of land degradation. In August. 1990 - Feb.1991, the country was occupied by Iraqi Troops. Military operations represented by troops transport on the fragile desert sur- 
face, maneuvering and construction of defense lines resulted in severe surface disruption. As stated by Misak 2003, some 6000 Iraqi Tanks \& Tracked Vehicles and 5145 Coalition Tanks \& Vehicles were moving on the desert of Kuwait. In addition, some 240,000 ground fortifications were established in Kuwait. Between 2007/2008 and 2017/2018 seasons, Kuwait experienced a drought episode. The average annual rainfall during the drought episode fluctuated between 35- and 75-mm. Strong winds with high speed, ranging between 50-60 km/ hour were recorded during the drought episode. As indicated in a huge number of publications, e.g., Omar et al. [1] Khalaf et al. [3] and Misak et al. [4], one of the main consequences of drought is the deterioration of vegetation cover.

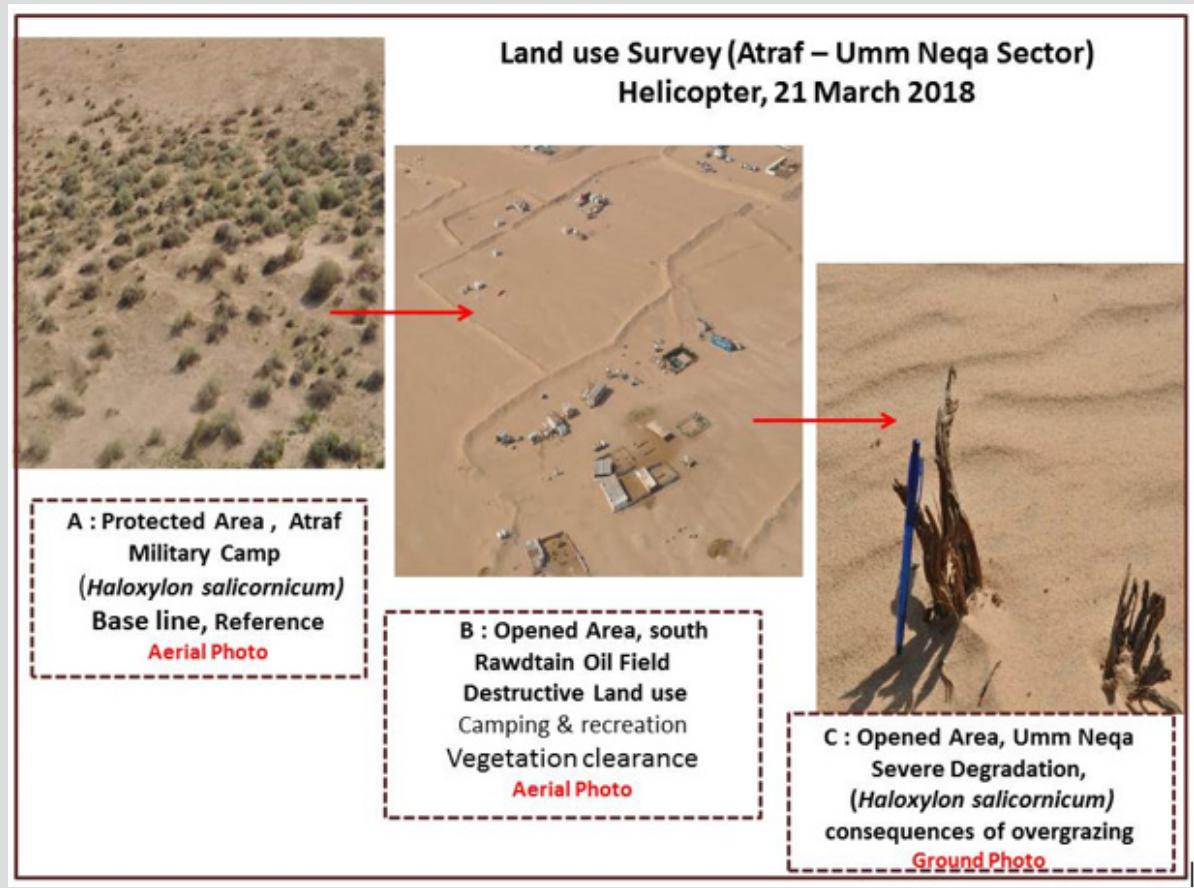

Figure 1: The interaction between land use types and land degradation (three cases).

Omar et al. [1] mapped eight major vegetation units in the terrestrial environment of Kuwait. The vegetation map was prepared by integrating the soil and vegetation information on a Geographic Information System (GIS). The vegetation units are: Haloxyletum (22.70\%), Rhanterietum (2.10\%), Cyperetum (26.90\%), Stipagrastietum (39.30\%), Zygophylletum (0.30\%), Centropodietum (1\%), Panicetum (0.70\%) and Halophyletum (1.90\%). The mentioned vegetation map was used as a baseline for comparison with the conditions of the year 2017. Justifications for selecting this map as a baseline include:

a) The map was developed based on advanced technology (Remote Sensing \&GIS) and

b) Some 8351 observation points were assessed for vegetation cover and soils.

On the other side, eight soil units were mapped by KISR1999. These soil units are: Aquisalids (7\%), Calcigypsids (6\%), Haplocalcids (8\%), Haplogypsids (0.05\%), Petrocalcids (11\%), Petrogypsids (33\%), Torriorthent $(0.08 \%)$ and Torripsamments (27\%). In Kuwait, land degradation directly affects economic and biological productivity as well as public health. The majority of the early studies on land degradation were focused on symptoms and causes of land degradation which are mainly related to socioeconomic conditions and natural factors. Mapping land degradation in Kuwait was not tackled in previous studies.

Land degradation processes prevail in the majority of the terrestrial environment of Kuwait. These processes include soil salinization and waterlogging (agricultural areas), loss of top soils (through both wind and water erosion), soil crusting, sealing and compaction, soil mining, vegetation degradation and loss of biodiversity. Several biophysical and socioeconomic land degradation indicators were identified by several authors, e.g., Khalaf et al. [59], Brown and Porembski [10,11], Al-Dousari, Al-Awadhi et al. [12,13], ; Omar et al. [1,14] , Misak [4], Al Dousari, Khalaf et al. [15], Misak et al. [15], the Kuwait National Committee for Combating Desertification (2014 \& 2015), Misak and Suleiman 2014 and Misak and Al Ghazali 2017. These indicators are differentiated into biophysical, socioeconomic and land use. Land degradation indicators in three different land uses were discussed by Misak [4]. These land uses are rangeland $(75 \%$ of the terrestrial environment of Kuwait), agricultural areas $(2.71 \%$ of the terrestrial environment of Kuwait) and quarry and dumps $(2.2 \%$ of the terrestrial environment of $\mathrm{Ku}$ wait). In these different land uses, soil, and vegetation degradation, loss of biodiversity and hydrological degradation prevail. 
Reversing the processes of land degradation through serious and sustainable control measures, as well as appropriate land use planning are the most significant challenges facing the real development of the terrestrial environment of Kuwait. The current study indicates that the total length of off-road vehicles is around $14,774.67 \mathrm{Km}$ ( $0.98 \mathrm{Km} / \mathrm{Km}^{2}$ ) of terrain environment of Kuwait Figure 2. As indicated from Figure 2, the off-road vehicles result in surface disruption for all land use types including protected areas (about $18 \%$ of the country) and rangeland grazing (close to $51 \%$ of the country). In addition, the off-road vehicles dissect all geomorphological units including sand dunes, playas, dry wadis, and hilly terrain Figure 3. shows the disruption caused by off-road vehicles. The goal of this study is to identify and characterize the land degradation hotspots (LDH) in the terrestrial environment of Kuwait and to discuss the interaction between land use types and the status of vegetation cover and soils types.

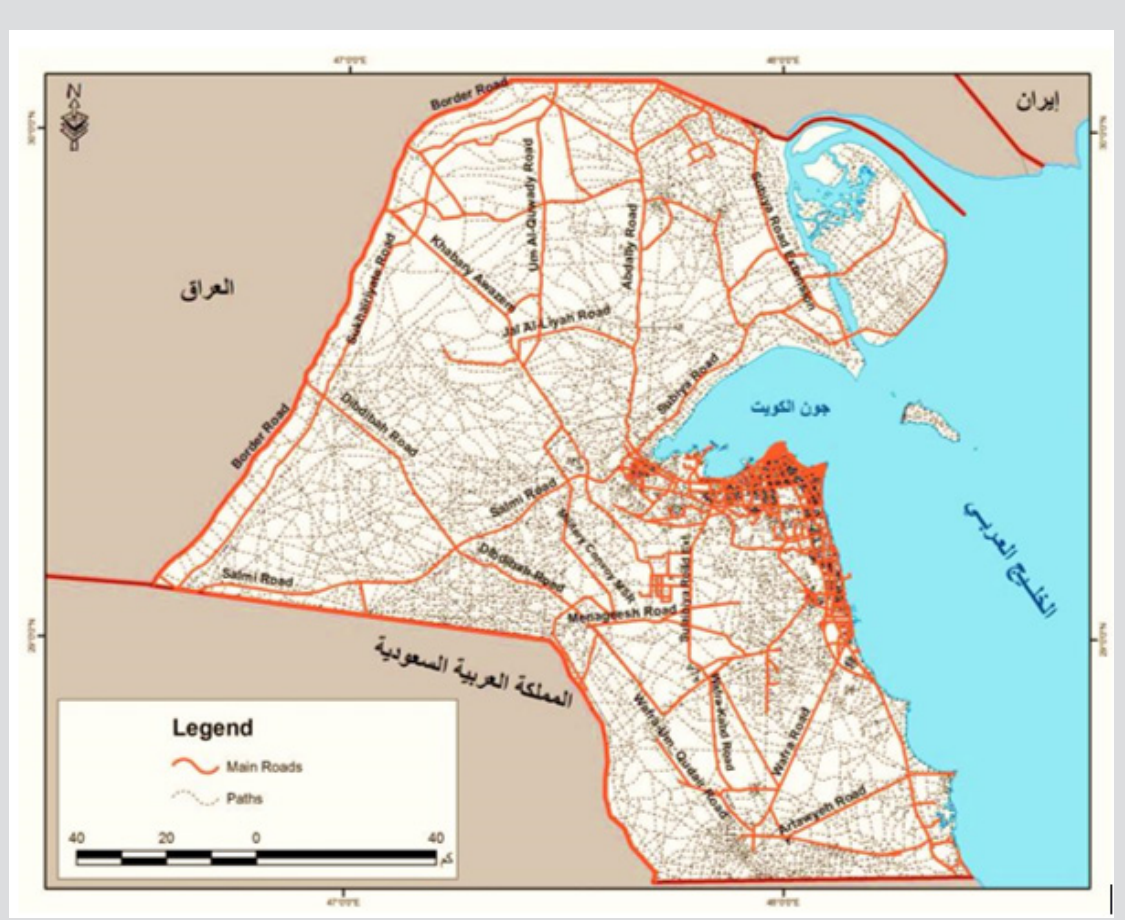

Figure 2: Map showing off-road vehicles in Kuwait, as of September 2017(Source: Kuwait Municipality, 2017).

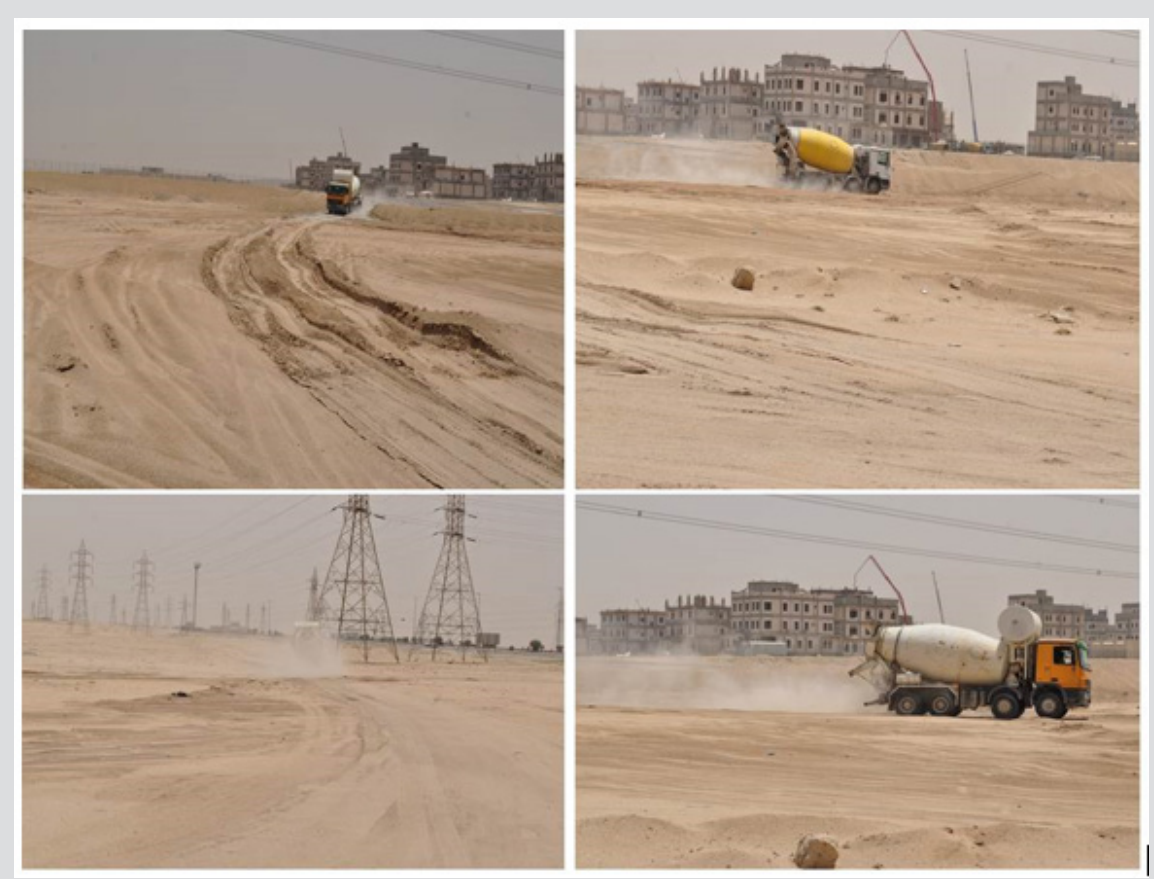

Figure 3: Surface disruption by offroad vehicles, Kabd Area (southwest Kuwait City), May 2018. 


\section{Materials and methods}

\section{Remote Sensing and Geographic Information System}

This study aims to detect and identify the land degradation hotspots (LDH). For this purpose, a low spatial resolution satellite image (Landsat 8, 25 September 2017, 15 m resolution) was used for the detection and delineation of hotspots and the analytical potential of GIS was effectively used to produce the final analysis and design in the form of maps. The primary data was collected from the entire study area and has been identified the locations of the degraded areas using the global positioning system (GPS) with extreme precision (latitude and longitude coordinates) and was saved in the system as a layer. For identification of hot spots using remote sensing, some observable ground objects were delineated. These include large trucks, water tankers, caravans, water wells, livestock sheds, portable livestock shelters and stores of animal feeds.
These objects which represent the tools for camping and grazing in the desert appear as black dots on the satellite image; therefore, the areas where the black dots appear on satellite image densely and confirmed by field survey are defined as hotspots where the soil and vegetation cover in these areas were subjected to severe deterioration due to human actions. The (ArcGIS S/W 10.5) was used in the current study to integrate the information of ground truth and satellite image to create a hotspots map. Three GIS map layers were overlayed on the hotspots map. These are offroad vehicles, soil types, and vegetation cover (Figures 4, 8 \& 9) respictively. These maps gave answers to many questions related to the extent of deterioration and its causes in the study area, and the economic, environmental and social impact on the Kuwaiti environment, then to determine the control measurements by the decision makers to mitigate and reduce this deterioration.

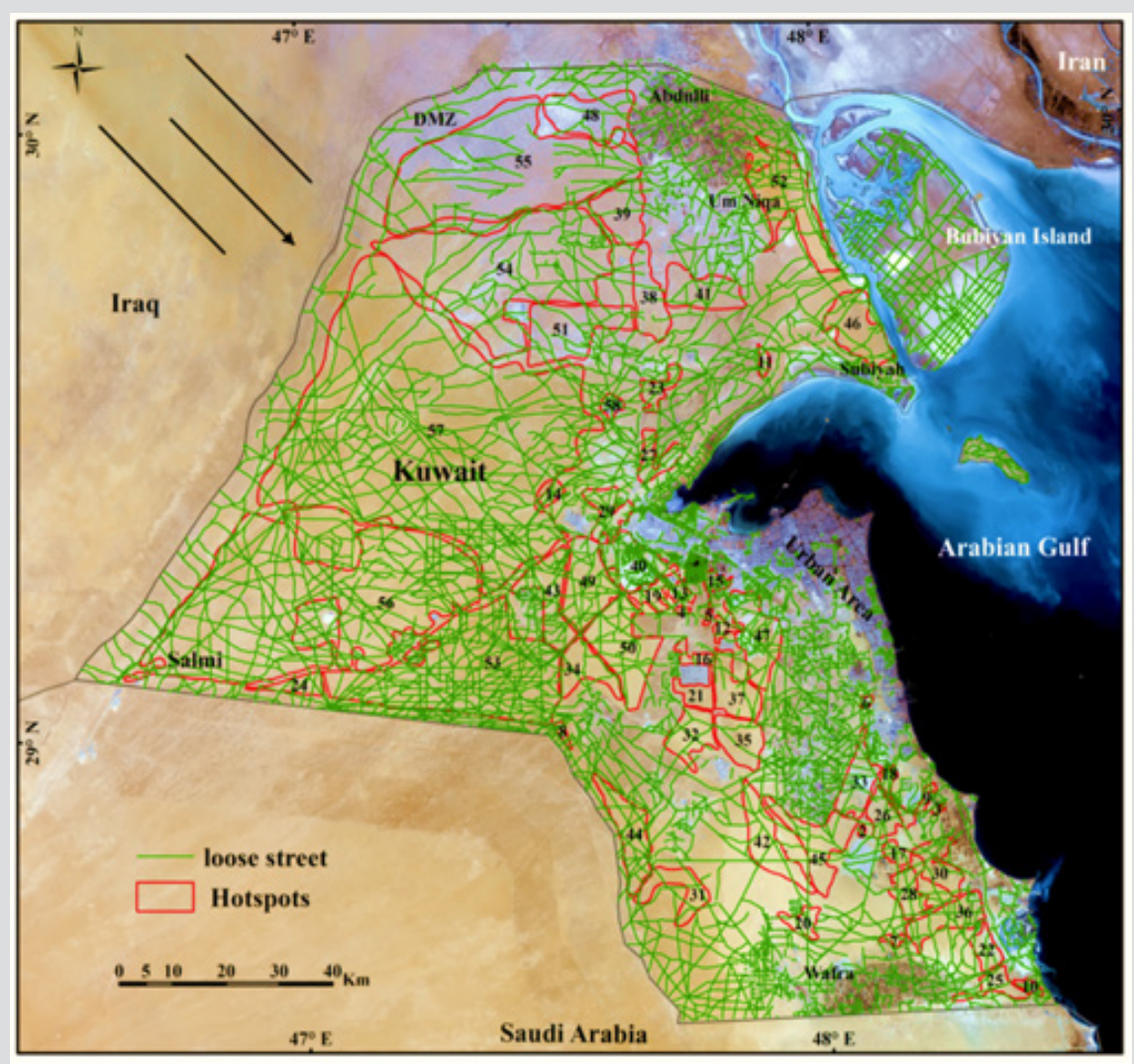

Figure 4: Hotspots on offroad vehicles (loose streets).

\section{The Ground Truth \& Field Observations}

During November 2017 - March 2018, seven field trips were arranged to several areas in the Terrestrial Environment of Kuwait. On 21 March 2018, an exploratory survey using low altitude of the low-speed helicopter was arranged to the northeastern part of Kuwait (16\% of the country). The purpose of this reconnaissance survey was to get information on current land uses. During the ground field trips, 25 observation points (01 - 025) and 19 control sites (C1-C19) were selected, Figure 5. shows the locations of the observation points and control sites. The 19 control sites are located in protected areas (including the Demilitarized Zone between Iraq and Kuwait). So they were used as a reference for the original healthy vegetation which is protected for at last two decades. The field survey for land degradation indicators of the hot spots was based on visual field evidence (Table 1). 
Table 1: land degradation indicators of the hot spots.

\begin{tabular}{|c|c|c|}
\hline \multicolumn{3}{|c|}{ Land Degradation Indicators of the Hot Spots } \\
\hline Land Degradation Indicator & Field Evidence & Remarks \\
\hline Vegetation degradation \& loss of biodiversity & $\begin{array}{l}\text { - No visible vegetation(bare land) in } \\
\text { comparison to the vegetation map of Omar et al. } \\
\text { 2001) and available control sites } \\
\text { Terrain dissection by intensive trials } \\
\text { created by off-road vehicles (density at last } \\
83 \% \text { ) }\end{array}$ & $\begin{array}{l}\text { Image of trails created by off-road vehicles of } \\
\qquad 2017 \text { was examined }\end{array}$ \\
\hline Soil losses (by wind) & Deflated land features, e.g. granule ripples & \\
\hline Soil losses (by water) & $\begin{array}{c}\text { - } \quad \text { Rills and gullies } \\
\text { - } \quad \text { Exposed bedrocks in water channels }\end{array}$ & \\
\hline Soil crusting, sealing, and compaction & $\begin{array}{l}\text { Continuous driving ( } 4 \times 4 \text { jeeps and } \\
\text { trucks) on the fragile desert surface } \\
\text { - Soil crusts of clayey soils }\end{array}$ & \\
\hline Soil mining & $\begin{array}{l}\text { Exploiting the soil for the } \\
\text { establishment of berms and bund walls of 1.5- } \\
2 \mathrm{~m} \text { high to protect facilities } \\
\text { - } \quad \text { Piles of excavated soils }\end{array}$ & \\
\hline
\end{tabular}

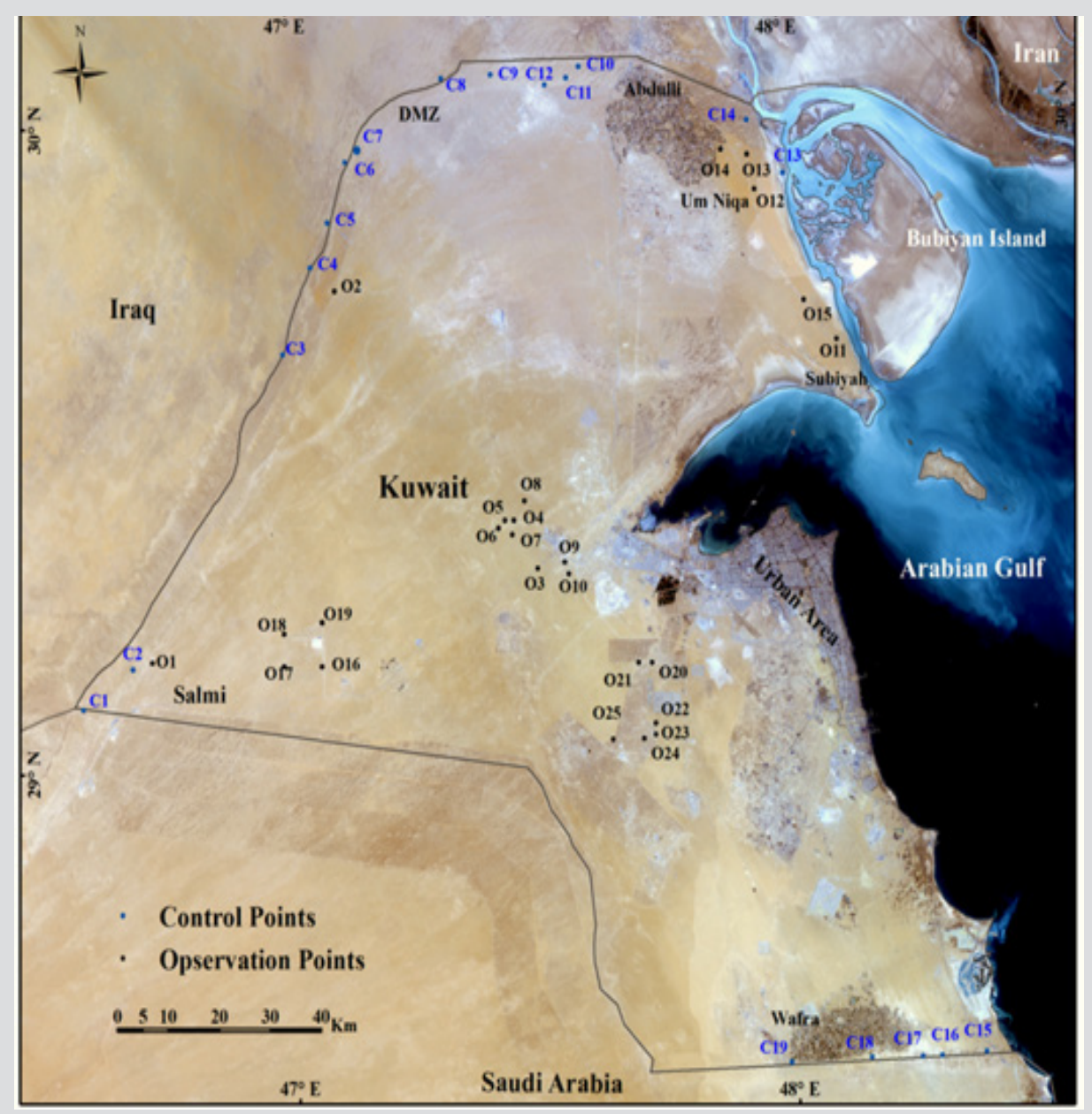

Figure 5: Landsat image, September 25, 2017, showing the observation points (black O1-25) and control points (blue C1-C32) truth. 


\section{Results and Discussion}

The development of low cost and simple techniques for detecting land degradation hot spots is a significant approach for monitoring and assessment of land degradation. The final output of the current study is maps, GIS layers and low-resolution satellite images for land degradation in Kuwait .Similar studies were carried in Ethiopia (Tor-G. Vager et al., 2013). The mentioned study demonstrated the utility of Landsat ETM + imagery for landscapelevel assessments of land degradation risk and soil condition through a combination of systematic field methodologies, infrared (IR) spectroscopy and ensemble modeling techniques. Kobayashi, \& Oki (2015) detected land degradation in Western Australia using free data like Landsat and Shuttle Radar Topography Mission DEM. Lanfredi et al. [16] proposed a procedure that integrates

Table 2: List of observation points for ground truth. multi-spectral satellite observations and air temperature data to detect areas where the current status of local vegetation and climate shows evident departures from the mean conditions of the investigated region.

\section{Field Surveys}

A field survey was carried out through observations, measurements, ground truth (for the remote sensing information) and photography. Some 25 observation points were assessed for vegetation, soils, land features, land degradation, and land use. The coordinates, ground elevation and the land features for the 25 observation points are shown in Table 2. The ground elevation varies between $267 \mathrm{~m}$ above sea level (observation point 01) to 3 $\mathrm{m}$ above sea level (observation point 011)

\begin{tabular}{|c|c|c|c|c|}
\hline \multicolumn{5}{|c|}{ List of Observation Points for Ground Truth } \\
\hline \multirow{2}{*}{ NO. } & Coordinates & Elevation & Land Features & \\
\hline & $\mathbf{N}$ & $\mathbf{E}$ & (m) & \\
\hline 01 & 29.1705 & 46.71458 & 267 & Wadi Al Rimth (Tributary of Wadi Al-Batin) \\
\hline 02 & 29.74282 & 47.09312 & 126 & sand dune_Al-Huwaimliyah (sumood) \\
\hline 03 & 29.30533 & 47.49463 & 143 & Al-Atraf area, southwest Ali Al Salem Air Base \\
\hline 04 & 29.38142 & 47.44798 & 169 & Al-Atraf area, northwest, Ali Al Salem Air Base \\
\hline 05 & 29.38177 & 47.43047 & 178 & Al-Atraf area, nort Salmi Road \\
\hline 06 & 29.36977 & 47.41682 & 171 & Al-Atraf area, northwest Ali Al Salem Air Base \\
\hline 07 & 29.35932 & 47.44507 & 158 & Al-Atraf area, west Ali Al Salem Air Base \\
\hline 08 & 29.41057 & 47.47035 & 159 & Al-Atraf area, north Ali Al Salem Air Base \\
\hline 09 & 29.31467 & 47.54877 & 126 & Al-Atraf area, south of Salmi Road \\
\hline 010 & 29.29647 & 47.55707 & 117 & Al-Atraf area, south of Salmi Road \\
\hline 011 & 29.6497 & 48.10832 & 3 & Sand sheet, Al Maghasil Area, Sabiyah -Umm Nega Road \\
\hline 012 & 29.88498 & 47.9481 & 13 & $\begin{array}{l}\text { Degraded sand sheet, the intersection between a cut to a military camp and } \\
\text { Sabiya-Umm Neqa Road main road. }\end{array}$ \\
\hline 013 & 29.93972 & 47.93493 & 15 & $\begin{array}{l}\text { Sand accumulation, the intersection between Abdali farms and Sabiya-Umm } \\
\text { Neqa Roads }\end{array}$ \\
\hline 014 & 29.94838 & 47.88202 & 19 & Umm Neqa dune \\
\hline 015 & 29.71235 & 48.0436 & 21 & Excavation for civil project. \\
\hline 016 & 29.16028 & 47.05643 & 253 & Sand sheet, Shaqiah site, south-east \\
\hline 017 & 29.16141 & 46.97946 & 262 & Sand sheet, Shaqiah site, southwest \\
\hline 018 & 29.21212 & 46.98034 & 239 & Sand sheet, Shaqiah site, northwest \\
\hline 019 & 29.22915 & 47.05784 & 233 & Sand sheet, Shaqiah site, northeast \\
\hline 020 & 29.15535 & 47.72223 & 74 & Sandy plain, southeast Kabd Station (KISR) \\
\hline 021 & 29.15618 & 47.69472 & 94 & Sandy plain, south Kabd Station (KISR) \\
\hline 022 & 29.06112 & 47.7268 & 100 & Sandy plain, Kabd animal production (Jawakheir) \\
\hline 023 & 29.04352 & 47.72678 & 110 & Sandy plain, Abdaliyah, eastern side \\
\hline 024 & 29.03778 & 47.70333 & 118 & Sandy plain, Abdaliyah, near the main gate \\
\hline 025 & 29.03768 & 47.64077 & 154 & Sandy plain, Abdaliyah, south-west \\
\hline
\end{tabular}

In general, the common characteristics of the majority of the 58 hotspots are:

a) Almost $100 \%$ vegetation degradation and loss of biodiversity b) Observable dead plant remains (stems and roots) Figure 6.

c) Development of granule ripples which indicate severe wind erosion (abrasion) under drought conditions. 
d) Adoption of nonsustainable measures such as earth berms \& bund walls.

e) Offroad vehicles which cause soil compaction

f) Gullies and rills which indicate soil loss by runoff water

These hot spots with a total area of $7590.3 \mathrm{~K}$ are delineated Figure 7. The study reveals a significant variation in the areas of the hot spots, ranging from about $2000 \mathrm{~km}^{2}$ (hot spot 57) to $1.2 \mathrm{~km}^{2}$ (hot spot 1) with average $132.9 \mathrm{Km}^{2}$. Based on their areas, the hot spots are categorized into five classes. These are: (Table 3).
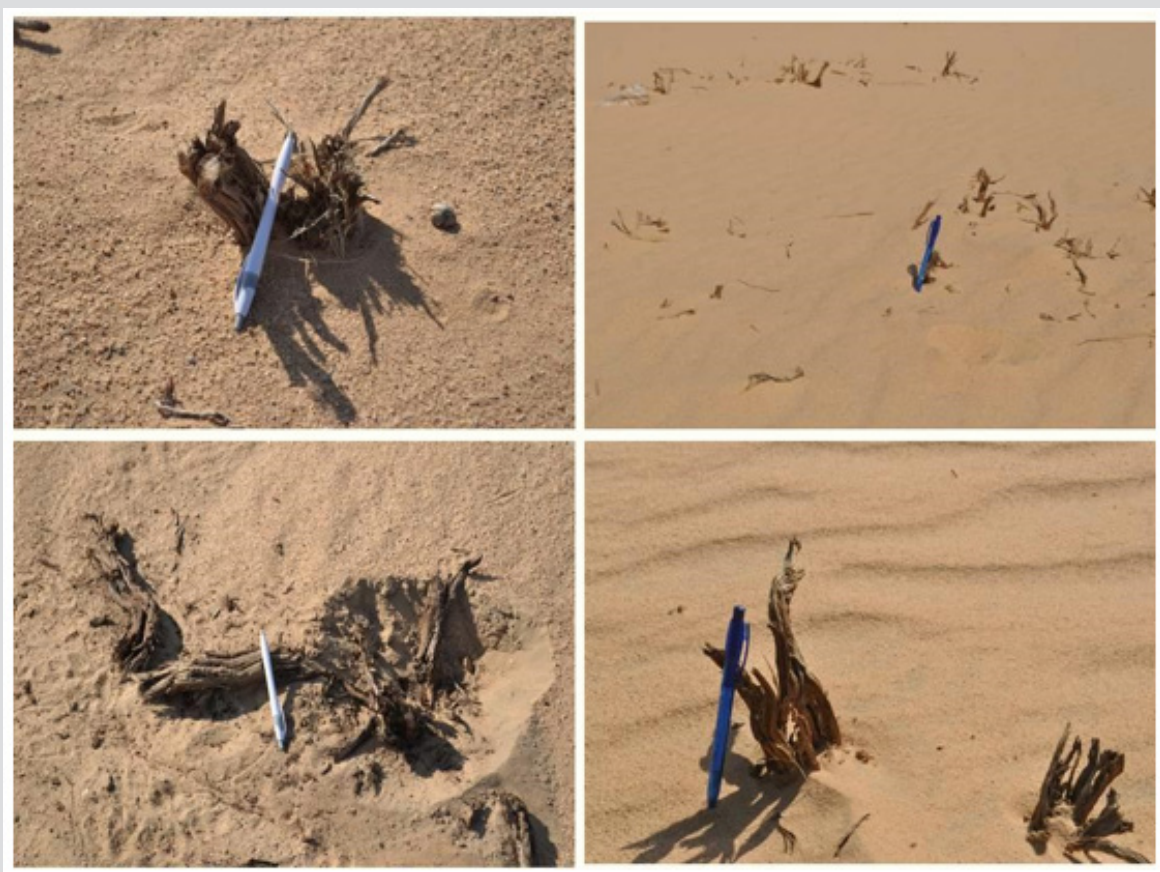

Figure 6: Degradation of Haloxylon salicornicum , hot spot no 52, the northeastern part of Kuwait. Note the difference in grain size and the active sand sheets (November 2017-March 2018).

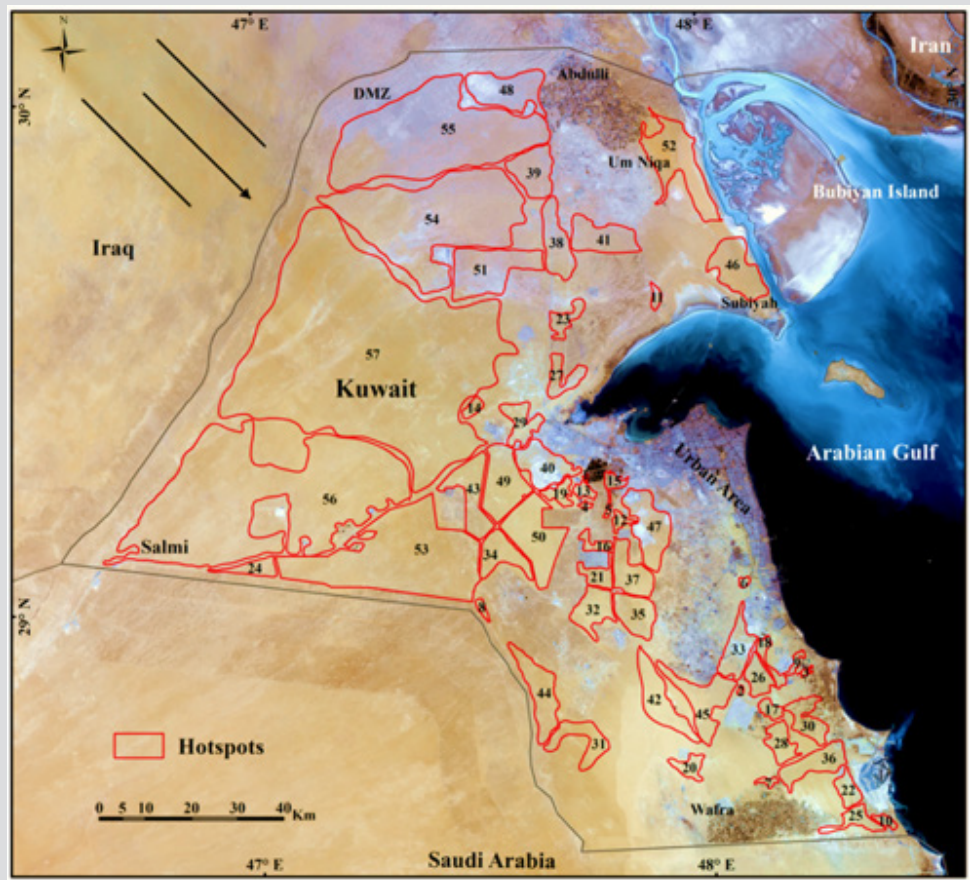

Figure 7: Landsat image acquired on September 25, 2017, with land degradation hotspots (LDH). The arrow indicates the northwesterly winds. 
Table 3: Basic information on the hotspots in Kuwait.

\begin{tabular}{|c|c|c|c|c|}
\hline \multicolumn{5}{|c|}{ Basic Information on the Hotspots in Kuwait } \\
\hline Hotspot & Area $\left(\mathrm{Km}^{2}\right)$ & Size & Land Use* & Land Degradation Indicators** \\
\hline 1 & 1.247 & very small & $\mathrm{A} \& \mathrm{~B}$ & $1 \& 2$ \\
\hline 2 & 2.144 & very small & $\mathrm{A} \& \mathrm{~B}$ & $1 \& 2$ \\
\hline 3 & 3.042 & very small & $\mathrm{A} \& \mathrm{~B}$ & $1 \& 2$ \\
\hline 4 & 3.156 & very small & $\mathrm{A} \& \mathrm{~B}$ & $1 \& 2$ \\
\hline 5 & 3.847 & very small & $\mathrm{A} \& \mathrm{~B}$ & $1 \& 2$ \\
\hline 6 & 4.323 & very small & A \&C & $1 \& 2$ \\
\hline 7 & 6.053 & very small & $\mathrm{A} \& \mathrm{~B}$ & $1 \& 2$ \\
\hline 8 & 6.919 & very small & $A \& B$ & $1,2 \& 3$ \\
\hline 9 & 7.99 & very small & $\mathrm{A} \& \mathrm{~B}$ & $1,2 \& 3$ \\
\hline 10 & 9.053 & very small & $A \& B$ & $1,2 \& 3$ \\
\hline 11 & 9.075 & very small & $A \& B$ & $1,2,3 \& 4$ \\
\hline 12 & 10.575 & medium & $A \& B$ & $1,2 \& 4$ \\
\hline 13 & 12.191 & medium & $A \& B$ & $1,2 \& 4$ \\
\hline 14 & 12.342 & medium & $A \& B$ & $1 \& 2$ \\
\hline 15 & 12.736 & medium & $A \& B$ & $1 \& 2$ \\
\hline 16 & 15.542 & medium & $A \& B$ & $1,2 \& 4$ \\
\hline 17 & 15.796 & medium & $A \& B$ & $1,2 \& 4$ \\
\hline 18 & 19.509 & medium & $A \& B$ & $1,2 \& 4$ \\
\hline 19 & 22.14 & medium & $A \& B$ & $1,2,3 \& 4$ \\
\hline 20 & 24.011 & medium & $A \& B$ & $1,2,3 \& 4$ \\
\hline 21 & 28.477 & medium & $A \& B$ & $1,2 \& 4$ \\
\hline 22 & 28.602 & medium & $A \& B$ & $1,2 \& 4$ \\
\hline 23 & 29.391 & medium & $A \& B$ & $1,2 \& 4$ \\
\hline 24 & 30.584 & medium & $A \& B$ & $1,2 \& 3$ \\
\hline 25 & 32.633 & medium & $A \& B$ & $1,2 \& 4$ \\
\hline 26 & 36.361 & medium & $A \& B$ & $1,2 \& 4$ \\
\hline 27 & 39.058 & medium & $A \& B$ & $1,2,3 \& 4$ \\
\hline 28 & 39.958 & medium & $A \& B$ & $1,2 \& 4$ \\
\hline 29 & 48.205 & large & $A \& B$ & $1,2,3 \& 4$ \\
\hline 30 & 51.193 & large & $A \& B$ & $1,2 \& 4$ \\
\hline 31 & 60.536 & very large & $A \& B$ & $1 \& 2$ \\
\hline 32 & 62.916 & very large & $A \& B$ & $1 \& 2$ \\
\hline 33 & 64.253 & very large & A, B \& C & $1 \& 2$ \\
\hline 34 & 64.324 & very large & $A \& B$ & $1 \& 2$ \\
\hline 35 & 64.744 & very large & $A \& B$ & $1,2 \& 3$ \\
\hline 36 & 67.714 & very large & A, B \&C & $1,2 \& 4$ \\
\hline 37 & 69.613 & very large & $A \& B$ & $1,2,3 \& 4$ \\
\hline 38 & 79.271 & very large & $A \& B$ & $1,2,3 \& 4$ \\
\hline 39 & 81.063 & very large & $A \& B$ & $1,2 \& 3$ \\
\hline 40 & 82.289 & very large & A, C & $12,3 \& 4$ \\
\hline 41 & 86.182 & very large & A, B \&D & $1,2,3 \& 4$ \\
\hline 42 & 90.955 & very large & $A \& B$ & $1,2,3 \& 4$ \\
\hline 43 & 92.079 & very large & $A \& B$ & $1,2 \& 3$ \\
\hline 44 & 92.462 & very large & $A \& B$ & $1,2,3 \& 4$ \\
\hline 45 & 98.347 & very large & $A \& B$ & $1,2,3 \& 4$ \\
\hline 46 & 100.291 & very large & $A \& B$ & $1,2 \& 3$ \\
\hline
\end{tabular}




\begin{tabular}{|c|c|c|c|c|}
\hline 47 & 105.963 & very large & C \&A & $1,2,3 \& 4$ \\
\hline 48 & 112.811 & very large & A, B \&C & $1,2,3 \& 4$ \\
\hline 49 & 114.737 & very large & A \& B & $1,2,4 \& 4$ \\
\hline 50 & 142.594 & very large & A \& B & $1,2 \& 4$ \\
\hline 51 & 148.576 & very large & A, B \& C & $1,2 \& 4$ \\
\hline 52 & 157.174 & very large & A,B \& & $1 \& 2$ \\
\hline 53 & 538.521 & very large & A, B\& E & $1,2,3 \& 4$ \\
\hline 54 & 631.221 & very large & C, A B & $1,2,3 \& 4$ \\
\hline 55 & 664.746 & very large & C \&A & $1,2,3 \& 4$ \\
\hline 56 & 1136.735 & very large & A, B \& E & $1,2,3 \& 4$ \\
\hline 57 & 2000.669 & very large & F, A, B, C \& E & $1,2,3 \& 4$ \\
\hline 58 & 13.4 & Small & C & $1,2,3 \& 4$ \\
\hline
\end{tabular}

Land use*

A: Rangelands grazing, B: Encampment (Temporary accommodation in the desert), C: Quarries and landfills, D: Oil, E: Water pipelines and wells \& F: military maneuvers

Land degradation indicators**

1: Vegetation degradation \& loss of biodiversity, 2: Soil losses (both by wind and water), 3: Soil crusting, sealing and compaction \& 4: Soil mining
a) very small (less than $10 \mathrm{~km}^{2}$ )
b) small $\left(10-20 \mathrm{~km}^{2}\right)$
c) medium $\left(20-40 \mathrm{~km}^{2}\right)$
d) large $\left(40-60 \mathrm{~km}^{2}\right)$
e) very large (more than $60 \mathrm{~km}^{2}$ )

Large and very large hot spots are distributed in the northern and western parts of the country. Coalescence of two or more small to medium hot spots results in large to huge spots (in the case of northern and western parts of Kuwait. Table 3 brief on the land use and land degradation indicators for the 58 hotspots. Rangeland grazing and encampment comprises $98 \%$ of land uses of

Table 4: Degraded soil types. the hotspots, Both the land uses are connected to each other. These main land uses were mainly concentrated in the hotspots 1 to 57 which covers a total area of $7575.9 \mathrm{~km}^{2}$. Hotspot 58 that covered an area of $13.4 \mathrm{~km}^{2}$ recorded no indicators of rangeland grazing and encampment due to this hot spot is located in a protected area where these activity is prohibited. As for the land degradation indicators such as vegetation deterioration, and soil losses (both by wind and water) were recorded in all the 58 hot spots (Table 3 ) [17-28].

\section{Soil Degradation}

The results of the present study indicate that the area of soil degradation is $7590.3 \mathrm{Km}^{2}$ (47\% of the terrestrial environment) ( Figure 8) and (Table 4).

\begin{tabular}{|c|c|c|c|c|}
\hline \multicolumn{5}{|c|}{ Degraded Soil Types } \\
\hline Soil Type & $\begin{array}{c}\text { Soil Type Area }\left(\mathbf{k m}^{2} \text { ) }\right. \\
\text { (Omar et al. 2001) }\end{array}$ & $\begin{array}{c}\text { Percentage of Soil Type Area } \\
\text { (Omar et al. 2001) }\end{array}$ & $\begin{array}{c}\text { Degraded Area 2017 } \\
\text { (km }{ }^{2} \text { (Current Study) }\end{array}$ & $\begin{array}{c}\text { Percentage of Degraded Area } \\
\text { 2017 (Current Study) }\end{array}$ \\
\hline Aquisalids & $1,211.8$ & $7 \%$ & 21 & $1.7 \%$ \\
\hline Calcigypsids & $1,065.2$ & $6 \%$ & 359.3 & $33.7 \%$ \\
\hline Haplocalcids & $1,350.95$ & $8 \%$ & 295.5 & $21.9 \%$ \\
\hline Haplogypsids & 8.1 & $0.05 \%$ & 1,259 & $?$ \\
\hline Petrocalcids & $1,928.3$ & $11 \%$ & 3,830 & $65.3 \%$ \\
\hline Petrogypsids & $5,735.6$ & $33 \%$ & 2.1 & $67.0 \%$ \\
\hline Torriorthents & 135.5 & $0.08 \%$ & 1,810 & $1.5 \%$ \\
\hline Torripsamments & $4,728.3$ & $27 \%$ & 7576.9 & $38.3 \%$ \\
\hline Total & $16,163.8$ & $92.1 \%$ & & $46.9 \%$ \\
\hline
\end{tabular}




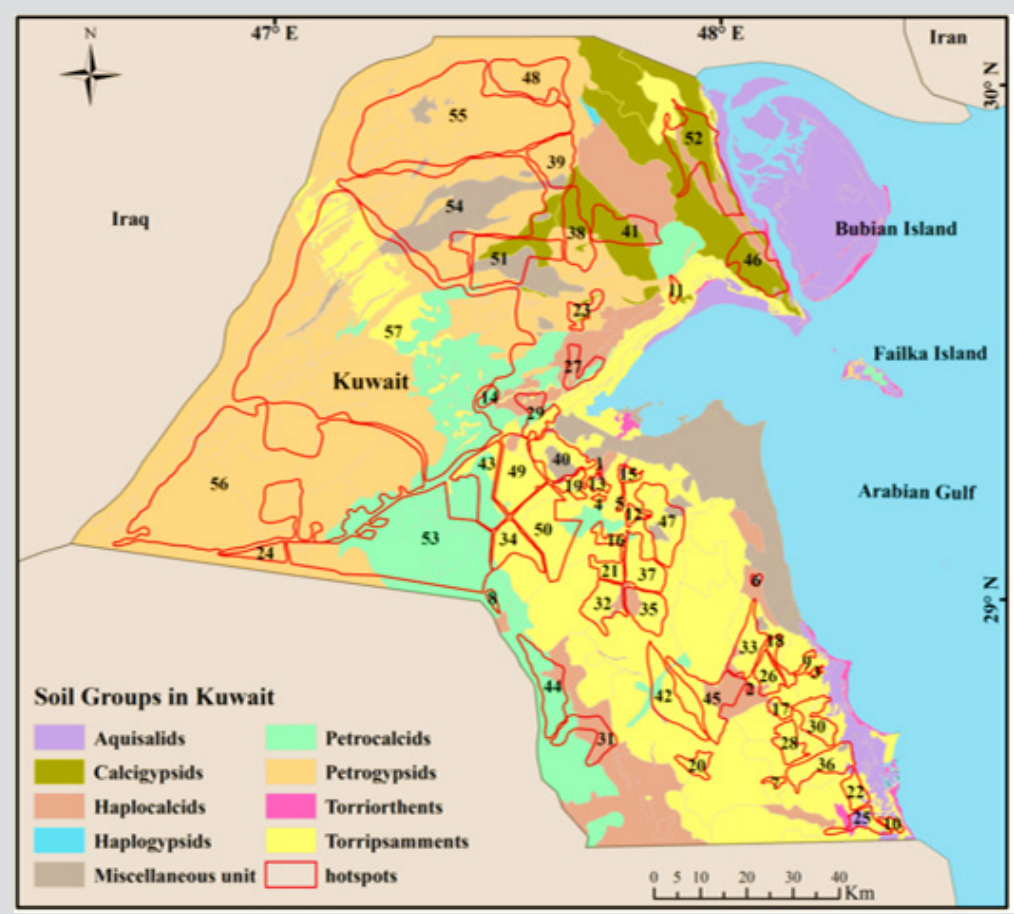

Figure 8: Hotspots on Soil Type Layer.

The highest vulnerable soil type to the deterioration of soil type were Petrogypsids $\left(3.830 \mathrm{Km}^{2}, 67 \%\right)$ and Petrocalcids $\left(1.259 \mathrm{Km}^{2}\right.$, $65.3 \%)$ and the lowest types were Aquisalids $\left(21 \mathrm{Km}^{2}, 1.7 \%\right)$ and Torriorthents $\left(2.1 \mathrm{Km}^{2}, 1.5 \%\right)$ (Table 4$)$.

\section{Vegetation Degradation}

The results of the present study indicate that the area of vegetation degradation is $7590.3 \mathrm{Km}^{2}$ (48.7\% of the total vegetation cover) (Figure 9) and (Table 5). The highest vulnerable vegetation type to the deterioration was Stipagrastietum $\left(3.688 \mathrm{Km}^{2}, 58 \%\right)$, then Cyperetum $\left(2.198 \mathrm{Km}^{2}, 50.4 \%\right)$ and the lowest types were Rhanterietum (36 Km², 11\%), Centropodietum (22.2 $\left.\mathrm{Km}^{2}, 14.1 \%\right)$, and Panicetum (12 $\mathrm{Km}^{2}, 14.1 \%$ ) (Table 5).

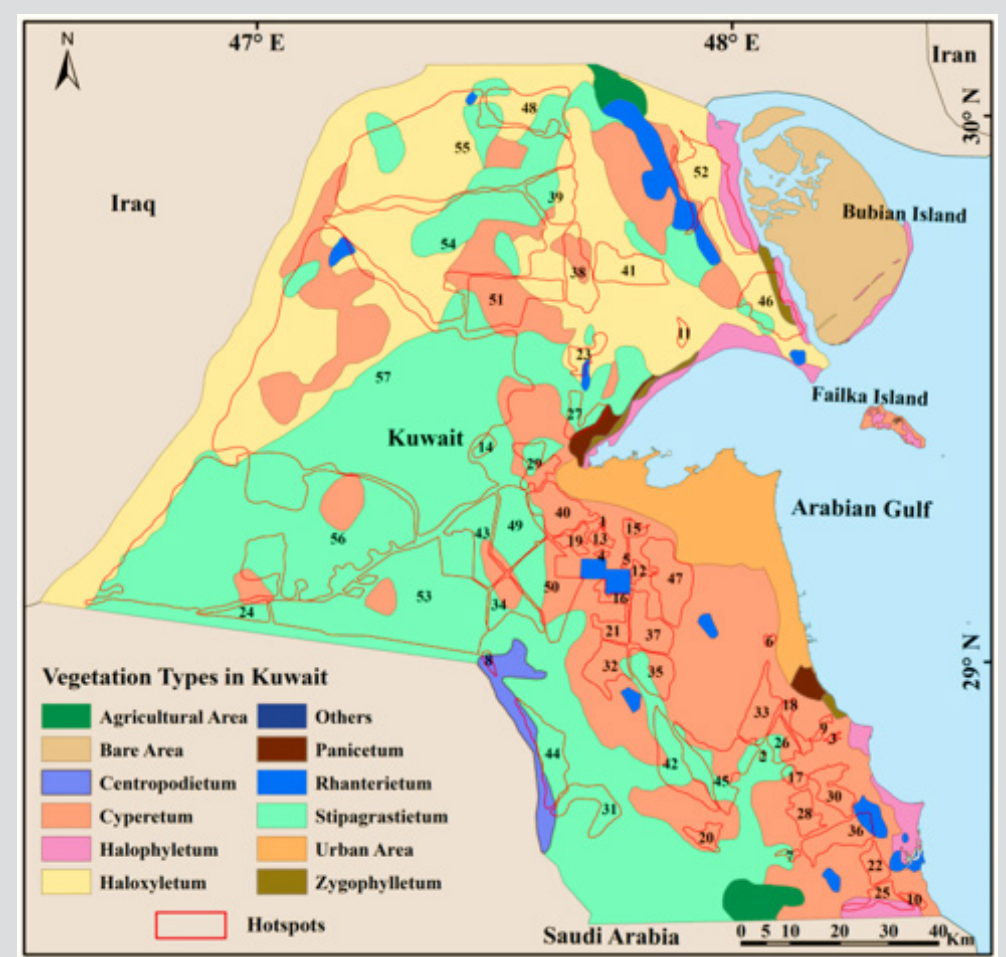

Figure 9: Hotspots on Vegetation Cover Layer. 
Table 5: Degraded vegetation types.

\begin{tabular}{|c|c|c|c|c|}
\hline \multicolumn{5}{|c|}{ Degraded Vegetation Types } \\
\hline Vegetation Type & $\begin{array}{c}\text { Area Covered by Plant } \\
\mathbf{( k m}^{2} \text { (Omar 2001) }\end{array}$ & $\begin{array}{c}\text { Percentage of Area Covered by } \\
\text { Plant (Omar 2001) }\end{array}$ & $\begin{array}{c}\text { Degraded Vegetation 2017 } \\
\text { (km²) }\end{array}$ & $\begin{array}{c}\text { Percentage of Degraded } \\
\text { (Current Study) } \\
\text { (Current Study) }\end{array}$ \\
\hline Haloxyletum & 3,765 & $22.70 \%$ & $1,485.3$ & $39.4 \%$ \\
\hline Rhanterietum & 327 & $2.10 \%$ & 36 & $11.0 \%$ \\
\hline Cyperetum & 4,394 & $26.90 \%$ & $2,198.2$ & $50.4 \%$ \\
\hline Stipagrastietum & 6,360 & $39.30 \%$ & 3,688 & $58.0 \%$ \\
\hline Zygophylletum & 58 & $0.30 \%$ & 25.2 & $43.4 \%$ \\
\hline Centropodietum & 158 & $1 \%$ & 22.2 & $14.1 \%$ \\
\hline Panicetum & 85 & $0.70 \%$ & 12 & $14.1 \%$ \\
\hline Halophyletum & 450 & $1.90 \%$ & 110 & $24.4 \%$ \\
\hline Total & 15,597 & $94.90 \%$ & $7,576.9$ & $48.6 \%$ \\
\hline
\end{tabular}

\section{Land Degradation Neutrality (LDN)}

Land Degradation Neutrality (LDN) in arid, semi-arid and dry sub-humid areas is a state whereby the amount of healthy land resources remains stable or increases within specified temporal and spatial scales (UNCCD, 2014). Based on analyses of information on the nature, extent, and magnitude of land degradation in the terrestrial ecosystem of Kuwait, a strategic LDN target is defined. It aims to reduce land degradation from $50 \%$ in the year 2019 to $10-15 \%$ in the year 2030. A twelve-year roadmap (2019-2030) is proposed. It consists of four programs:

a) GIS-based knowledge support system (2019 -2023),

b) Public awareness and capacity building (2019-2023),

c) Sustainable land use program (2020-2023) and

d) Restoration/rehabilitation program (2023-2030).

\section{Conclusions \& Recommendations}

Vegetation and soil degradation affects about $50 \%$ of the terrestrial environment of Kuwait which covers about $15.130 \mathrm{~km} 2$ (85\% of Kuwait). The main objective of this study was to detect and assess degraded areas in the terrestrial environment of Kuwait. A qualitative and quantitative approach was adopted through integratingremote sensing (Landsat8, September 2017), Geographic Information System (ArcGIS S/W 10.5) and field investigations. The vegetation map [1] showing eight vegetation units was used as a baseline data for comparison with the vegetation conditions of the year 2017. On the other side, the soil map (KISR, 1999) showing eight soil units was used as a reference for comparison with the soil conditions of the year 2017. The study mapped and characterized some 58 land degradation hotspots with a total area of about 7590.3 Km2. Significant variations were observed concerning the sizes, land use and land degradation indicators of the 58 hot spots. Seven land use types were recorded. The most significant of which were rangelands grazing, encampment (temporary accommodation in the desert), military maneuvers and quarries and landfills.
Four mainland degradation indicators were reported. These are vegetation degradation \& loss of biodiversity, soil losses (both by wind and water), soil crusting, sealing and compaction \& soil mining. It is indicated that for $98 \%$ of the hot spots, rangelands grazing and encampment are the main land uses. Both land uses are connected to each other. They were recorded in hotspots 1-57 $\left(7,576.94 \mathrm{~km}^{2}\right)$. The only hot spot where no rangeland grazing, is hot spot $58\left(13.4 \mathrm{~km}^{2}\right)$.Concerning land degradation indicators, vegetation degradation and soil losses (both by wind and water) were recorded in the 58 hot spots. Currently, most of the hotspots act as anthropogenic sources for sand and dust. Compared to the baseline data, some $48.7 \%$ of the vegetation and $47 \%$ of the soils were degraded during the period between 2001 to 2017. it is strongly recommended to develop a 12-year roadmap (20192030) to reverse land degradation.

\section{Acknowledgment}

Deep thanks and appreciations to Engineer Ahmad Othman, GIS Section, KISR for providing recent satellite image and his valuable comments.

\section{References}

1. Omar S, Misak R, King P, Shabbir S, Abo Rizq H, et al. (2001a) Mapping the vegetation of Kuwait through reconnaissance soil survey. Journal of Arid Environment 48(3): 341-355.

2. Omar S, Misak R, Minkarah H, King P, Kwarting A, et al. (2001) Landuse mapping for the State of Kuwait using the Geographical Information System (GIS). Arab Gulf Journal of Scientific Research 19(2): 59-65.

3. Khalaf FI, Misak RF, Al Awadi J (2013) Land use Planning for Controlling Land degradation in Kuwait Developments in Soil Classification. Land use planning and Policy Implications, Springer, pp. 609-689.

4. Misak RF (2003) Classes of land degradation in the Terrestrial Environment of Kuwait. In Application of New Technology for Improvement of Desert Environment, Kuwait-Japan Symposium, State of Kuwait.

5. Khalaf FI (1989) Desertification and Aeolian processes in the Kuwait desert. Journal of Arid Environment 16(2): 125-145.

6. Omar S (1991) Dynamics of range plants following 10 years of protection in arid rangelands of Kuwait. Journal of Arid Environments 21(1): 99111. 
7. Zaman S (1997) Effects of rainfall and grazing on vegetation yield and cover of two arid rangelands in Kuwait. Environmental Conservation. 24(4): 344-350.

8. Misak R, Al Awadhi J, Al Sudairawi M (1999) Assessment and controlling land degradation in Kuwaiti desert ecosystem. In: Proc. Conf. on the Impact of Environmental Pollution on the Development in the Gulf Region, Kuwait, p. 15-17.

9. Brown $\mathrm{G}$ (2003) Factors maintaining plant diversity in degraded areas of northern Kuwait. Journal of Arid Environ 54(1): 183-194.

10. Brown G, Porembski S (1998) Flora and vegetational aspects of miniature dunes in a sand-depleted Haloxylon salicornicum community in the Kuwait desert. Flora 193(2): 133-140.

11. Brown G, Porembski S (2000) Phytogenic hillocks and blow-outs as 'safe sites' for plants in an oil-contaminated area of northern Kuwait. Environmental Conservation 27(3): 242-249.

12. Al Awadhi J, Misak R, Omar S (2003) Causes and consequences of desertification in Kuwait. A case study of land degradation. Bulletin of Engineering Geology and the Environment 62(2): 107-115.

13. Al-Awadhi J, Omar S, Misak R (2005) Land degradation indicators in Kuwait. Land Degradation and Development 16 (2): 163-176.

14. Omar S, Bhat NR, Shahid SA, Assem A (2005) Land and vegetation degradation in war-affected areas in the Sabah Al-Ahmad nature reserve of Kuwait: a case study of Umm Ar Rimam. Journal of Arid Environ 62(3): 475-490.

15. Misak R, Khalaf F, Omar S (2013) Managing the hazards of drought and shifting sands in drylands (the case study of Kuwait), Developments in Soil Classification, land use planning and Policy Implications. Springer pp703-729.

16. Lanfredi, M, Coppola R, Simoniello T, Coluzzi R, D’Emilio M, et al. (2015) Early Identification of Land Degradation Hotspots in Complex BioGeographic Regions. Remote Sens 7(6): 8154-8179.

17. Al Dousari A, Misak R, Shahid S (2000) Soil compaction and sealing in Al Salmi area. Journal of Land Degradation \& Development 11(5): 401-418.

\section{ISSN: 2574-1241}

DOI: 10.26717.BJSTR.2019.14.002487

Abeer H Al Saleh. Biomed J Sci \& Tech Res

(C) This work is licensed under Creative (c) Commons Attribution 4.0 License

Submission Link: https://biomedres.us/submit-manuscript.php
18. Al Dousari A (2005) Causes and indicators of land degradation in northwestern part of Kuwait. Arab Gulf Journal of Scientific Research 23(2): 69-79.

19. KISR (1999) Soil Survey for the State of Kuwait. AACM International, Adelaide, Australia. 1: 270.

20. Kobayashi C, Oki K (2015) Mapping of land degradation and its factors using landsat and DEM in the Western Australian wheatbelt. 2015 IEEE International Geoscience and Remote Sensing Symposium (IGARSS).

21. Misak R, Al Ghazali F (2017) Causes and indictors of land degradation in the Terrestrial Environment of Kuwait. Journal of the Gulf and Arabian Peninsula, University of Kuwait. No 165-vol.43

22. Misak R, Suleiman M (2014) Controlling land degradation using environmentally friendly materials (the Case of Kuwait). Journal of Arid Land Studies 24(1): 73 -76.

23. Misak R, Al Dousari A (2013) Prolonged Drought Issues and DLDD (Desertification, Land Degradation, and Drought) in Kuwait. Invited paper, Kubuqi International Desert Forum (KIDF), China.

24. Misak R, Kwarteng A, Al Sudairawi, M Omar S, Al Obaid, et al. (2000) Controlling land degradation in several areas in Kuwait. Final Report. KISR6002 pp. 234.

25. Misak RF (2003) Military Operations as a Major Cause of Soil Degradation and Sand Encroachment in Arid Regions (the Case of Kuwait). Proceeding of Desert Technology. $7^{\text {th }}$ International Conference, Jodhpur, India, 14: 25-28.

26. (2015) National Committee for Combating Desertification in Kuwait 2015: Strategy of land degradation control in Kuwait-technical report EPA.

27. Omar S, Misak R, Shahid SA, Malik R, Madouh H, et al. (2001b) Rehabilitation of Kuwait's Rangelands for Sustainable Yield, Final Report. KISR6087 pp. 210.

28. Vågen TG, Winowiecki LA, Abegaz A, Hadgu KM (2013) Landsat-based approaches for mapping of land degradation prevalence and soil functional properties in Ethiopia. Remote Sensing of Environment 134: 266-275.

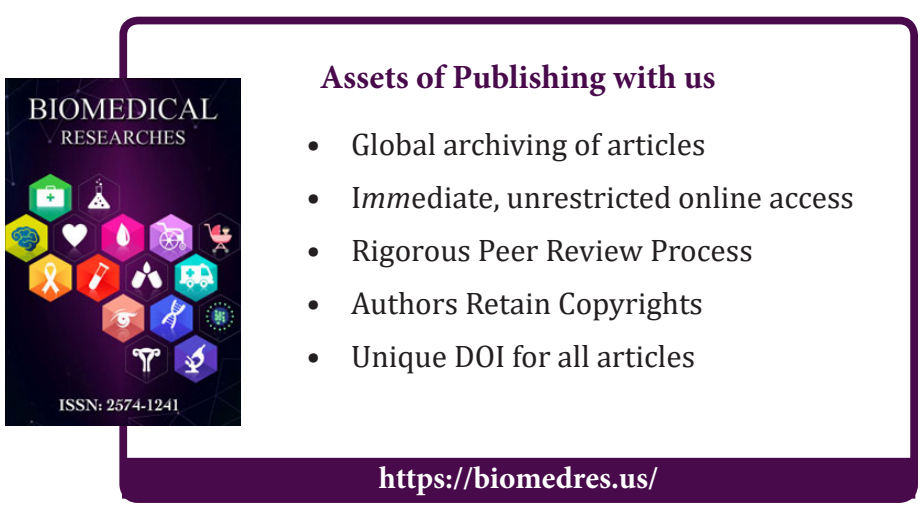

